\title{
PACKAGING RADAR: A PRELIMINARY REFERENCE FOR PACKAGING DESIGN IN A SYSTEMIC AND COMPLEX CONTEXT
}

\author{
R. M. Sastre ${ }^{凶}$, I. C. de Paula, C. F. Zeni and M. E. S. Echeveste \\ Universidade Federal do Rio Grande do Sul, Brazil \\ $\square$ ricsastre@gmail.com
}

\begin{abstract}
This study aims to generate a referential basis on which the designer can reflect about and explore scenarios during the structural and graphic packaging projects. "Packing Radar (RE)" has been compiled over years of research as it is spread across different sources and areas of expertise. This qualitative research uses content analysis and expert's opinions. The (RE) proposition shows its potential for improvement and diagnosis of sustainable packaging projects, of teaching activities and packaging professionals graduation.
\end{abstract}

Keywords: life cycle assessment (LCA), methodical design, packaging

\section{Introduction}

Packaging is casing, container or any form of packaging, whether removable or not, intended to cover, bundle, pot, protect, maintain or facilitate their marketing. Packaging is a system whose function is technical and commercial and aims to package, protect (from the production process to consumption), inform, identify, promote and sell a product. Packaging is the element that protects what it sells, besides selling what it protects. Packing is not only about wrapping content securely, but also dosing it and taking it to the consumer in one convenient unit. The packaging found in supermarkets and stores is the result of the action of a complex and multidisciplinary system, resulting from the work of several specialists who develop complementary activities, such as researchers, designers, operators, among others involved in its design.

Designers, however, for meeting deadlines and customer demands (Briefing), do not always consider a systemic look at the process, which is essential in a circular economy environment. The result is packaging that easily converts to waste, which has negatively impacted the environment. Packaging has been present in society since the day the need to protect, contain and transport goods was discovered. Initially, as reported by Cavalcanti (2006), man began to use plant leaves, leather and animal bladder as packaging raw material. After, it adopted new technologies, such as ceramics, glass, fabric, wood, paper, steel and plastics (PP, PET, PE, among others).

According to Mestriner (2002), life in big cities today would not be possible without the intensive use of packaging to provide food supplies and consumption of its millions of inhabitants. With the development of the consumer market, packaging was adding importance and the primary functions were expanded as a result of self-service. Since packaging is an integral part of the product, in most cases, the consumer does not dissociate the product from the packaging, making it necessary to go deeper into the subject, Mestriner (2002). 
According to Cavalcanti (2006), old qualities, such as transport and moisture resistance, remain essential, but necessarily supplemented by other important ones, such as the identification of the manufacturer of the packaged product and the seductive power exerted on buyers. What was a simple anonymous wrapper has become a tool for advertising and marketing at the point of sale, especially for managers of small and medium enterprises. According to SEBRAE, in Brazil there are 6.4 million establishments, of which $99 \%$ are micro and small enterprises (MPE). MPEs account for $52 \%$ of jobs in the private sector (16.1 million), and this majority do not have significant sums to invest in marketing.

It is considered that the packaging goes through constant improvements by the production processes, by the improvement of new raw materials and mainly by their design. It is important for the professional responsible for packaging development (designer) to consider the sustainability aspects in the projects, as it has also been seen as a big villain, impacting ecosystems whenever it is poorly designed and improperly discarded by the user at any point in the packaging life cycle (Brod, 2004; Calver, 2009; Mestriner, 2018; Negrão, 2008; Peltier, 2009).

From a knowledge point of view, packaging is not owned by a particular area. Design courses usually have subjects that prepare professional designers, but it is also content in courses such as food engineering, materials engineering, pharmacy, logistics and others. Each area of knowledge explores its most relevant aspects such as the types of materials in its composition and its compatibility with food and medicine, design methods, creative process and consumer attractiveness (Allen et al., 2000; Le Hir, 1997; Collaro, 2005; Moore, 2004; Carvalho, 2008). In fact, much of this content is consolidated in non-academic books, articles and databases as websites of world class entities such as ABRE (Brazilian Packaging Association); ABTG (Brazilian Graphic Technology Association); Packaging Institute; Pack Magazine; Embanews, Packaging Connections from India, World Packaging Organization, Canadian packaging, Ambalaza newspaper, Packaging Europe, Pack World, among others).

This reality forces professionals interested in the subject to make an Olympic turn in academic and non-academic literature, which is not always easily accessible and analyzed. Given this scenario, the present study aims to compile the knowledge and generate a referential basis on which the designer can reflect and explore scenarios during the conception of the structural and graphic packaging design, taking into account that the knowledge about the packaging is contained in several areas of knowledge, the following research question arises: is it possible to conceive a referential model about the packaging in a single instrument?

The theoretical content that supports the proposed referential basis, which was called "Packaging Radar", has been compiled over years of the author's research on the subject, which has been consolidated in some of his publications (Sastre, 2004, 2006, 2013, 2014, 2015, 2016, 2017; Sastre et al., 2018a, 2018b; Sastre and Echeveste, 2019). Over time, despite this author's attempts to generate a reference that synthesizes the investigated knowledge, the chosen consolidation formats favored some particular area, without providing the benefit and breadth that knowledge required. Finally, the packaging Radar consolidates this effort, having as its context unit its life cycle, an element that enabled the realization of the compiled theoretical content.

From the theoretical point of view, the Packaging Radar allows, at the same time, to have a systemic view and to synthesize knowledge of different natures, which were dispersed, all in one instrument. From a practical point of view, Radar can be used for: improvements to existing designs and packaging classification; creative action for the development of sustainable packaging; in teaching and training activities for packaging professionals in technical and higher courses that study this subject, such as: design, food engineering, logistics, among others.

\section{Theoretical review}

The literature review about packaging allows to segregate some categories of information that are often cited in different sources. We chose to present some in this theoretical framework, due to the importance it acquired in content analysis. Unlike the new types of materials and technologies used in packaging projects that belong to the frontier of knowledge and are published in scholarly journals of relevance, the information in this theoretical framework is already consolidated by use and is available in technical books. Thus, the sources used in this theoretical framework were extracted mostly from books and compiled materials of class entities linked to the theme, with technically curated contents for professionals. 


\subsection{Life cycle}

Packaging, like any product, has a life cycle and its development process must consider product integrity, customer satisfaction and the environment. The process begins with the extraction of the raw material from nature and its subsequent transformation. The third step is where the packaging design (structural and graphic) is concepted by a studio or design agency that will send it to the printing industry. After the packaging production, the pot and distribution to the points of sale, making it available to consume. Finally, there is the disposal, treatment and sorting of packaging waste. These steps allow the return of packaging to industry through recycling. (Peltier, 2009; Bohlmann 2004; Bridgens, 2018; Zampori, 2013).

\subsection{Function}

Over the last few years, numerous functions have been added to packaging. Primary functions - like containing, protecting, transporting and exposing (Gurgel, 2007; Moura and Banzato, 1997; Negrão, 2008). Other functions were added, such as: sales, sales promotion and support for marketing actions, branding support, among others (Calver, 2009; Mestriner, 2018; Coles, 2004). According to the authors mentioned, this is fundamentally due to changes in the way of life in contemporary society. Economic, technological, marketing, communication and environmental issues were added to primary concerns. For Gurgel (2007), packaging performs the communication function of the product concept. The packaging should draw attention at the point of sale and arouse the desire to buy. According to Mestriner (2002), it is a component in the product's price formation, as it can be considered as material for the industry that uses it to pack its product. To maintain product's integrity, new technologies such as blending materials and developing sustainable raw materials have emerged to aid packaging, utilizing sophisticated materials and differentiated production methods that result in better product conservation and allow market expansion to other distant countries. Furthermore, there is a sociocultural function that can be seen in some packages that reveal the expression of a particular society, as well as historical facts.

\subsection{Classification}

Packaging is generally classified into the following types, according to Carvalho (2008), into primary, secondary and tertiary (Figure 1).

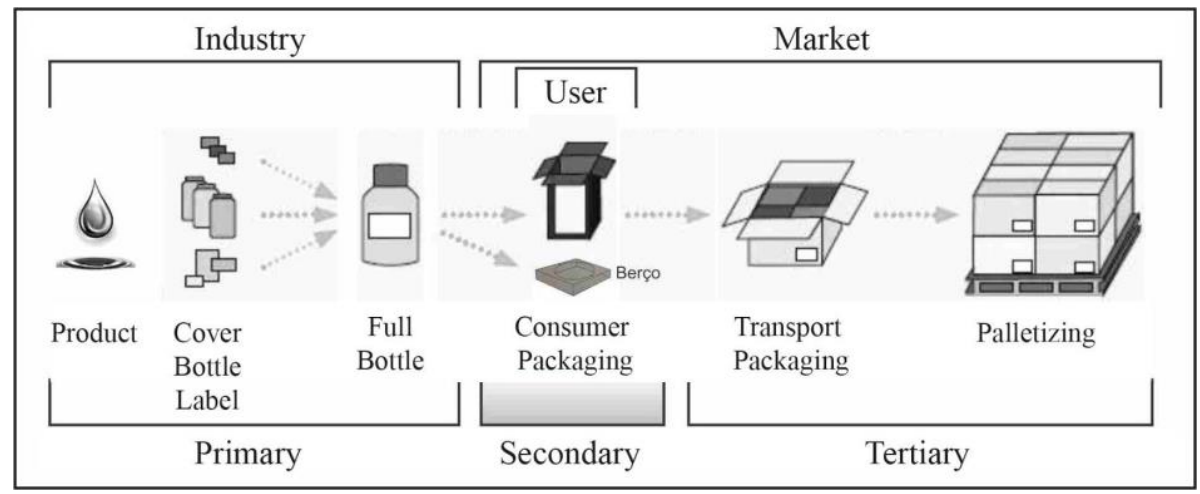

Figure 1. Packaging classification

The primary ones are those used by the industry to fill by the product (lid, bottle and label). Secondary packaging is the consumer packaging, that one in contact with the user and exposed at the point of sale. Transport packages are tertiary and contain, in an organized manner, all the previous elements (Allen et al., 2000; Le Hir, 1997; Collaro, 2005; Moura and Banzato, 1997; Carvalho, 2008). For safety and maintaining product integrity purposes, a cradle may be used inside the consumer packaging to ensure that a bottle will not be damaged during transport, for example. In some cases, transportation packaging is the same as consumer packaging, as seen in larger products such as appliances and machines. Expanding this classification, there are fourth level packaging or containers, 
which facilitate the transportation and storage, and the fifth level, used for long distance shipping, such as containers, Moura and Banzato (1997).

\subsection{Materials and processes}

Packaging manufacturing processes are divided into the shape production and printing processes, varying according to the type of raw material used. One of the basic premises for developing a packaging project is to understand its manufacturing process and the feasibility of the project. Due to the numerous materials and methods available, this task becomes complex and paramount in this process. According to Moura and Banzato (1997) the choice of packaging type is fundamentally based on the material that will build it, its characteristics and properties, considering the needs of the product, manufacturing, physical distribution and end customer. The material processing determines aspects that a packaging may have. The main materials used nowadays are: wood, paper, metal, plastic and glass. New materials, like multi-layer packaging, as well as the development of sustainable materials, such as polymers made from plant sources and reuse of waste, are constant novelties in the packaging sector.

About printing processes, according to Fernandes (2003), they are means of production capable of making one or several copies of a given image. Printers that use inks may or may not require matrices. Those that do not use matrices are digital printers that can be electrostatic or inkjet, also known as laser printers. According to Baer (1999), most printing processes use matrices in their production and are subdivided by the characteristic of shapes. Relevographic - are the matrices that have relief, as the flexography cliché and movable typography types, used in flexible plastic packaging. Planographic are the flat shapes such as lithographic printing using a stone as a matrix and offset printing using an aluminum plate used for paper packaging. Encavographs - these are notched dies such as the gravure cylinder and pad printing silicone, usually for larger print runs. Permographic - these are forms that ink penetrates and surpasses paper such as screen printing, for direct printing on pots, for example.

\subsection{Environmental guidelines}

Environmental sustainability refers to systemic conditions from which human activities, on a global or local scale, do not disturb natural cycles, beyond the limits of ecosystems' resilience on which they are based and, at the same time, do not impoverish the natural capital that will be inherited by future generations. The concept of sustainable packaging is directly related to minimizing environmental impact, and looking at the life cycle becomes fundamental, (Manzini, 2005; Pereira, 2012). In this context, the Brazilian Packaging Association - ABRE, considered the most important and representative class entity of the sector in Brazil, in its advanced environmental and sustainability studies committee, proposed the industry self-assessment environmental indicators for continuous improvement. These indicators are compiled in a spreadsheet and are related to each stage of the packaging life cycle. These guidelines were based on the Global Protocol on Packaging and Sustainability published by The Consumer Goods Forum.

\section{Methodology}

This research is qualitative and uses content analysis technique composed of three macro steps highlighted as essential of this methodology, suggested by Bardin (1977) and Moraes (1999), and adapted by the authors of the present study. Two design professionals participated in the construction of the packaging Radar. Three other professionals, a packaging specialist with 23 years of experience and two product development management specialists with more than 20 years of experience each, were consulted in evaluating the results of each step.

\section{Categorization:}

It is a procedure of grouping data, considering the common part between them. They are classified by similarity or analogy (nearby features and meanings), according to previously established criteria or defined during the process. Categorization is a classification operation of the elements of a message, following certain criteria, facilitating the analysis of information (Moraes, 1999). Part of the compiled content is from a personal collection of the main author of this article, who has been studying 
packaging for 23 years. The collection was expanded by searching for articles in databases such as EBSCO, Emerald, Science Direct, Springer, Web of Science, and Willey. The keywords used for Boolean searches and operators were "pack*" and "sustainab"" and "eco". 2.348 articles were searched, and 318 articles were considered for reading and analysis, which brought the packaging as the main theme. The articles confirmed the consolidated knowledge from the books, and eventually added new materials and techniques from the knowledge frontier. There were also included in the compiled content the graphical versions of references that synthesized the knowledge investigated in consolidation formats such as table-type, process, lists and mental maps, elaborated over time by the main author of this work. Two design professionals compiled and organized this content, as well as researched through an article called "Sustainable Packaging: the state of the art of producing theses and dissertations in postgraduate design courses", published by the authors at the 13th Congress of research in Design, the R\&D (Sastre et al., 2018a).

\section{Description:}

Once the categories are defined and the constituent material of each one of them is identified, it is necessary to communicate the result of this work. The description is the first moment of this communication. In general, the organization of this description will be determined by the category system constructed throughout the analysis. This is the moment to express the meanings captured and intuited in the analyzed messages Moraes (1999). For the description stage, the authors defined as context unit the "life cycle" of the packaging product. The units of analysis emerged naturally from the analyzed content and they are: functions, classification, materials and processes, stakeholders and environmental indicators.

\section{Interpretation:}

This step seeks to achieve a deeper understanding of message content through interpretation. Content analysis exercises this interpretation effort in greater depth and deals with content manifested by the authors, as well as latent content (implicit sense capture). The theory is built on the data basis and analysis categories. The theoretical basis emerges from information and categories, so the very construction of theory is an interpretation (Bardin, 1977; Moraes, 1999). Radar pilot versions were prepared at this stage and subjected to critical analysis by the packaging specialist and product development management specialists. Changes were being made to generate the final version of this tool.

\section{Results and discussion}

In this stage, we present the results of the theoretical compilation related to packaging, called Packaging Radar. For its analysis, the three stages of content analysis proposed in the methodology of this study are used. Radar content dimensions were composed by researching various materials and areas as indicated (Table 1).

Table 1. Package Radar content dimensions

\begin{tabular}{|l|l|l|l|l|l|l|}
\hline $\begin{array}{l}\text { Sources/knowledge } \\
\text { areas }\end{array}$ & Design & Engineering & Pharmaceutics & Administration & Chemistry & Advocacy \\
\hline Norm & & $\mathrm{X}$ & $\mathrm{X}$ & & & $\mathrm{X}$ \\
\hline Books & $\mathrm{X}$ & $\mathrm{X}$ & $\mathrm{X}$ & $\mathrm{X}$ & & \\
\hline Articles & $\mathrm{X}$ & $\mathrm{X}$ & $\mathrm{X}$ & $\mathrm{X}$ & $\mathrm{X}$ & \\
\hline Websites & $\mathrm{X}$ & & & & & \\
\hline Institutions & $\mathrm{X}$ & $\mathrm{X}$ & & $\mathrm{X}$ & & $\mathrm{X}$ \\
\hline
\end{tabular}

The Packaging Radar was being built over several iterations (performed in years), assuming different formats. It was initially designed as a table grouping relevant packaging information. The table was converted into a matrix to identify correlations between the contents, but still was not expressing the levels of interactions between the dimensions. Later, the matrix evolved into two mind maps. The first one allowed to accumulate a large volume of information about the packaging, but without any 
interaction between the dimensions. Then second version of the map showed a greater degree of logical organization, using life cycle steps, but in linear format.

Both mind maps made it difficult to interact between the dimensions of analysis, however, the linear representation used the life cycle as a contextual element, which naturally referred to the circularity, due to system's feedback. Thus, the circular version emerged, called Radar, this time grouping the dimensions with readability and allowing interactions between them. By interaction is meant the possibility of visualizing combinations between these dimensions during the creative process or packaging analysis.

\section{Categorization:}

The proposed categories emerged from the theoretical framework and were divided into context unit and analysis unit. The categorization process should be understood in its essence as a data reduction process. In the context unit is the packaging life cycle, that is the starting point of the Radar. Located at the center of the Radar, it is composed of eight determinant phases for the division of the proposed categories. Through the life cycle it was possible to achieve a pattern in the themes, involving the determining aspects in the construction or analysis of a packaging, and this grouping was possible not only on the life cycle stages, but also in the relationships between them.

The Packaging Radar presents the six proposed categories that were arranged radially from the center to the edges, obeying a sequence in order of importance in the construction and analysis of a packaging. These are: functions; ranking; materials and processes; stakeholders and environmental guidelines.

\section{Description:}

This step describes the aspects presented in the Packaging Radar applied to the main design method in packaging development (Table 2).

Table 2. Relationship between packaging Radar dimensions and design phases

\begin{tabular}{|l|l|}
\hline Design phases of packing & PR dimensions applicable to design stage \\
\hline Requirements gathering & Life cycle; Stakeholders \\
\hline Conceptualization and strategy & Functions; Classification; Stakeholders; environmental guidelines \\
\hline Developing solutions & Structural and graphical design (radial reading) \\
\hline Prototyping & Materials and processes \\
\hline Validation & Use Packaging Radar as a checklist \\
\hline
\end{tabular}

Packaging Radar can be used to analyze existing packaging (A), to develop new designs (B), or (C) to analyze/propose innovative combinations of their dimensions (i.e. functions $\mathrm{x}$ materials x process). An example of (C) is the case of Tetra Pack. The integrated solution for their multi-layer packaging, innovative at the time, involved the combination of the "raw material", the "structural design", the "packaging manufacturing and packing" and the "recycling solution" dimensions. The integrated solution had the involvement of different stakeholders. It is virtually impossible to describe life cycle actions without mentioning the impacted or impacting parts of each life cycle stage, which is why it was included among the Radar dimensions.

\section{Interpretation:}

It presents the conceptual structure of the packaging Radar and how it should be read by the user. The starting point is the life cycle, through which it was possible to organize the categories cyclically, reading from the center to the edges (radial) and clockwise (Figure 2). In the materials and processes category, a clockwise (circumferential) reading is suggested, starting with the extraction of the raw material until the filling process - only on this category a sequential reading is recommended. It is also suggested to cross-read between life cycle stages, shuffling the information in order to find crossmeanings between dimensions, which may occasionally lead to a new (innovative) interpretation through unpretentious reading (creative lateral thinking). 


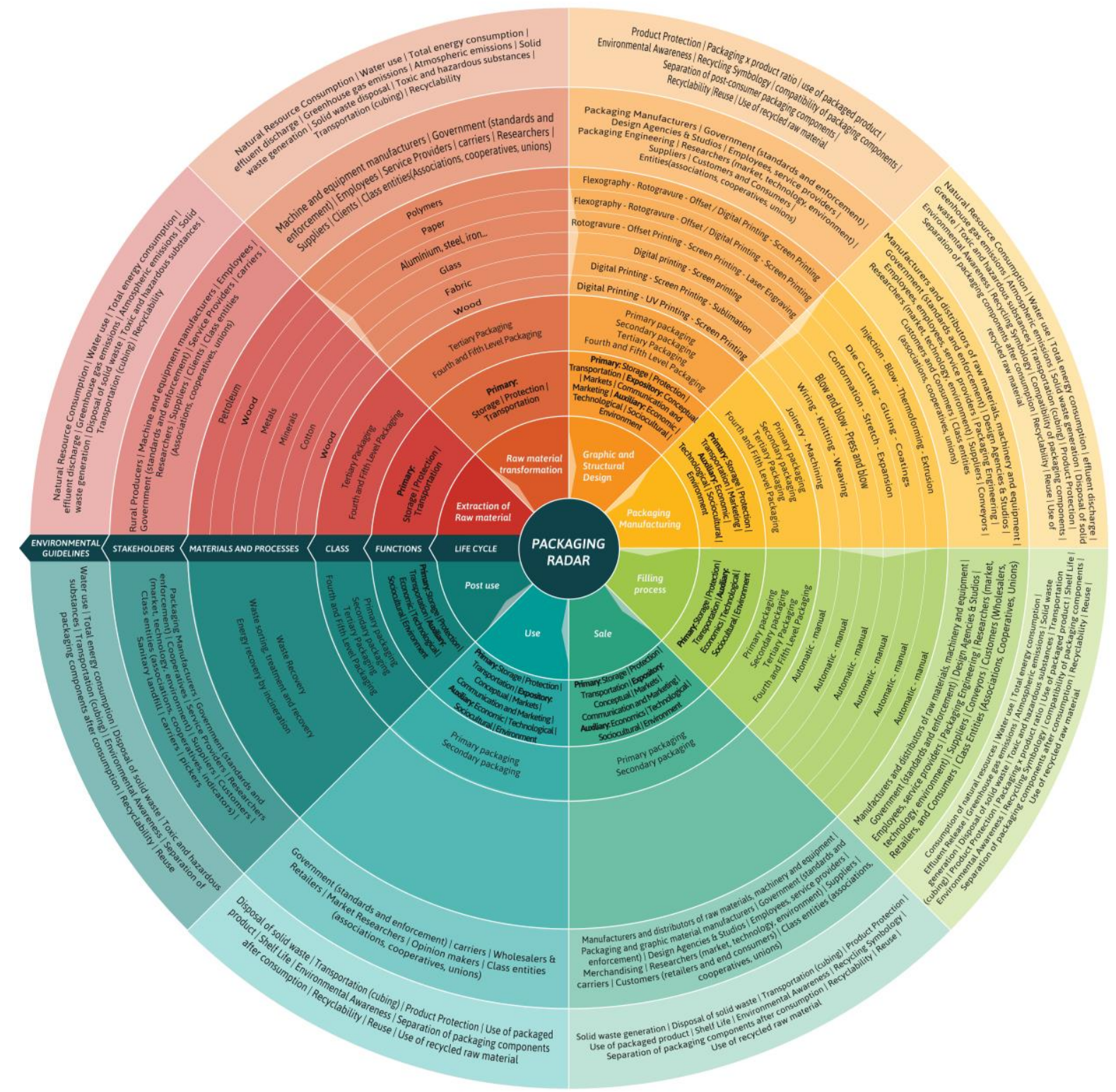

Figure 2. Packaging Radar

The texts are arranged in the reading direction and it is not necessary to move the sheet to read it in its entirety. In some cases, content is presented in more than one phase of the life cycle, such as materials and processes in the sales and use stages. At each stage of the life cycle, the elements that make up the analysis are expanded. In this sense, as an example, it is explained in the extraction of the raw material stage, its functions, classification, materials and processes, stakeholders and environmental guidelines. Each level is superimposed on the other, allowing the reader to make combinations between categories, for example, in packaging design, the designer can analyze sustainability guidelines in all dimensions as well as test interactions between them.

\section{Packaging Radar application examples}

From a practical point of view, the Radar can be used for: improvements to existing designs and packaging classification; in creative action for the development of sustainable packaging; teaching and training activities for packaging professionals.

Therefore, we propose the practical application of Packaging Radar through the diagnosis of three existing projects in the market. In this analysis, some of the objects of study in the packaging Radar are contextualized, seeking greater technical detail of the project. 


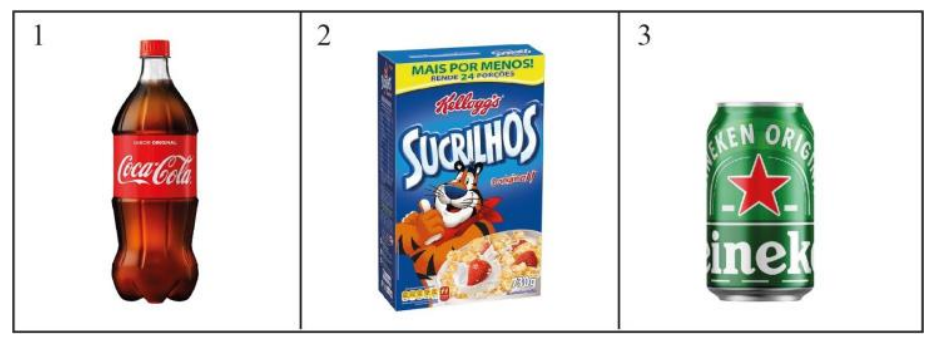

Figure 3.

Table 3. Partial application of Radar to Coca Cola packaging (01)

\begin{tabular}{|l|l|l|l|l|}
\hline \multicolumn{1}{|c|}{ Life cycle } & Functions & Classification & \multicolumn{1}{|c|}{ Materials } & Production process \\
\hline Raw material extraction & Primary & & Petroleum & \\
\hline transformation of raw material & Primary & & $\begin{array}{l}\text { Polymer } \\
\text { (PET/PEBD/PE) }\end{array}$ & \\
\hline Project & $\begin{array}{l}\text { Primary } \\
\text { Expository } \\
\text { Auxiliaries }\end{array}$ & Primary & Graphic and estructural & \\
\hline Packing production & & & Graphic and estructural & Injection/ Breath \\
\hline Fill & & & & Automatic \\
\hline Sale & $\begin{array}{l}\text { Expository } \\
\text { Auxiliaries }\end{array}$ & & & \\
\hline Use & Auxiliaries & & & \\
\hline Post use & Auxiliaries & & Recovery and sorting & \\
\hline
\end{tabular}

Table 4. Partial application of Radar to Sucrilhos Kellogs packaging (02)

\begin{tabular}{|l|l|l|l|l|}
\hline \multicolumn{1}{|c|}{ Life cycle } & Functions & Classification & \multicolumn{1}{c|}{ Materials } & Production process \\
\hline Raw material extraction & Primary & & Wood & \\
\hline transformation of raw material & Primary & & Paper & \\
\hline Project & $\begin{array}{l}\text { Primary } \\
\text { Expository } \\
\text { Auxiliaries }\end{array}$ & Secondary & Graphic and estructural & \\
\hline Packing production & & & Graphic and estructural & Print/cut/collage \\
\hline Fill & & & & Automatic \\
\hline Sale & $\begin{array}{l}\text { Expository } \\
\text { Auxiliaries }\end{array}$ & & & \\
\hline Use & Auxiliaries & & Recovery and sorting & \\
\hline Post use & Auxiliaries & & . & \\
\hline
\end{tabular}

Table 5. Partial application of Radar to Heineken packaging (03)

\begin{tabular}{|l|l|l|l|l|}
\hline \multicolumn{1}{|c|}{ Life cycle } & Functions & Classification & \multicolumn{1}{c|}{ Materials } & Production process \\
\hline Raw material extraction & Primary & & Alumina & \\
\hline transformation of raw material & Primary & & Metal - aluminium & \\
\hline Project & $\begin{array}{l}\text { Primary } \\
\text { Expository } \\
\text { Auxiliaries }\end{array}$ & Primary & Graphic and estructural & \\
\hline Packing production & & & Graphic and estructural & Print/ stretch \\
\hline Fill & & & & Automatic \\
\hline Sale & $\begin{array}{l}\text { Expository } \\
\text { Auxiliaries }\end{array}$ & & & \\
\hline Use & Auxiliaries & & & \\
\hline Post use & Auxiliaries & & Recovery and sorting & \\
\hline
\end{tabular}

The possibilities of analysis and data crossing of Packing Radar are multiple, thus, the tables above illustrated some points of interaction between life cycle and the functions, classification, materials and production processes. Stakeholders and environmental guidelines were not considered in these tables that 
emphasized the functional and productive aspects, notwithstanding two elements that can assist in decision making because they guide sustainable packaging designs when necessary. Analyzing the life cycle of each of the examples, Table 3 presents a packaging made up of 03 types of polymers, (PET in the bottle, PEHD in the cap and PELD in the label). The mixing of materials makes the recycling process difficult, however, it makes it possible if there is proper separation and proper routing. Table 4 exemplifies a paper packaging, easily recyclable and without mixing raw materials. The last example is an aluminum can, a raw material with high added value, in countries like Brazil, its recycling rate is almost $100 \%$.

\section{Conclusion}

The value perception brought by the Packaging Radar proposed in this paper will be more concrete to a reader or professional affected by the complexity that represents the universe of packaging design. The breadth and depth of the theme can be perceived by the diversity of authors and sources cited throughout its construction. From both academic and practical point of view, it is unthinkable to design a packaging without a thorough reflection on the guiding elements of a project, presented on the Packaging Radar. All waste generated by packaging is assumed to be a bad design, that is, a project that did not consider the life cycle stages and their interactions. Packaging is considered multidisciplinary because it involves several areas of knowledge, such as: engineering, design, communication, law, administration, logistics, environmental management, among others. The participation of packaging and product development process management experts in this artifact elaboration upheld the generated constructs. Anyway, it is understood that it should be submitted to other professionals, for the purpose of verifying its accuracy in each dimension of Radar analysis, because the number of analysts was a limitation of this work phase. It was also a limitation in this article not to provide practical examples of the applications idealized for Radar use, as they require a lot of descriptive space.

An important consequence of this study was the reflection on the very concept of packaging presented initially. Due to its importance in the world scenario of sustainability and its complexity, it is proposed to expand it, as presented below by the authors: "Packaging are containers or wrappers, whose primary functions are to contain, protect and transport goods, and can be classified as complex and systemic, encompassing predictable and or unexpected interactions between their parts and processes and should therefore be considered from the perspective of their entire life cycle.

This study was limited to presenting the proposition of an integrative theoretical model, not providing a deepening on the Radar elements, such as stakeholder analysis, discussion about sustainability guidelines, detailing about materials and new materials, printing processes, packaging manufacturing, as well as their functions and classification. Future studies on the theory suggest a Packaging Radar approach to the methods of product development, service development, product-service system, among others. It is recommended as a practical application that designers involved with packaging consult the Radar before executing their projects in order to meet the demands of their entire chain.

\section{References}

Ambalaza Journal, Available at: http://www.ambalaza.hr/en/journal (accessed 5.11.2019).

Associação Brasileira de Embalagem - ABRE, Available at: http://www.abre.org.br (accessed 08.01.2019).

Baer, L. (1999), Produção gráfica, SENAC, São Paulo.

Bardin, L. (1977), Análise de conteúdo, Edições 70, Lisboa.

Bohlmann, G.M. (2004), Biodegradable Packaging Life-Cycle Assessment. Wiley InterScience. Available at: www.interscience.wiley.com (accessed 29.11.2004) https://doi.org/doi:10.1002/ep.10053

Bridgens, B. (2018), "Creative upcycling: Reconnecting people, materials and place through making”, Journal of Cleaner Production, Vol. 189, p. 145-154. https://doi.org/10.1016/j.jclepro.2018.03.317

Brod, Jr. (2004), Desenho de embalagem: projeto mediado por parâmetros ecológicos, Dissertação de mestrado [Mestrado em Engenharia de Produção], Universidade Federal de Santa Maria, Santa Maria.

Calver, G. (2009), O que é design de embalagens? Bookman, Porto Alegre.

Canadian Packaging, Available at: https://www.canadianpackaging.com (accessed 05.11.2019).

Carvalho, M.A. (2008), Engenharia de embalagens: uma abordagem técnica do desenvolvimento de projetos de embalagem, Novatec, São Paulo.

Cavalcanti, P. (2006), História da embalagem no Brasil, Grifo Projetos Históricos e Editoriais, São Paulo.

Collaro, A.C. (2005), Produção visual e gráfica. Summus, São Paulo. 
Coles, R.E. (2004), Estudos de embalagens para o varejo, Blusher, São Paulo.

Fernandes, A. (2003), Fundamentos de produção gráfica para quem não é produtor gráfico, Rubio, Rio de Janeiro.

Gil, A.C. (2010), Como elaborar projetos de pesquisa, Atlas, São Paulo.

Gurgel, F.D.A. (2007), Administração da embalagem, Thomson, São Paulo.

Allen, Popovich and Ansel. (2000), Farmacotécnica: formas farmacêuticas \& sistemas de liberação de fármacos, Editorial Premier, São Paulo.

Le Hir, A. (1997), Noções de farmácia Galênica, Andrei Editora, São Paulo.

Manzini, E. (2005), O desenvolvimento de produtos sustentáveis, Editora da Universidade de São Paulo, São Paulo.

Mestriner, F. (2002), Design de embalagem: curso básico, Pearson Makron Books, São Paulo.

Mestriner, F. (2002), Design de embalagem: curso avançado, Pearson Makron Books, São Paulo.

Mestriner, F. (2007), Gestão estratégica de embalagem, Pearson Prentice Hall, São Paulo.

Mestriner, F. (2018), Inovação na embalagem, Mbooks, São Paulo.

Moore, G. (2004), Nanotecnologias em embalagens, Blusher, São Paulo.

Moraes, R. (1999), “Análise de conteúdo”, Revista Educação, Porto Alegre, Vol. 22 No. 37, pp. 7-32.

Moura e Banzato, Reinaldo e Maurício (1997), Embalagem, unitizacão \& conteinerização, IMAM, São Paulo.

Negrão, C. (2008), Design de embalagem: do marketing à produção, Novatec, São Paulo.

Packaging Conections, Available at: https://www.packagingconnections.com (accessed 05.11.2019).

Packaging Europe, Available at: https://packagingeurope.com (accessed 05.11.2019).

Pack World, Available at: https://www.packworld.com (accessed 05.11.2019).

Peltier, F. (2009), Design sustentável: caminhos virtuosos, Senac, São Paulo.

Pereira, P.Z. (2012), Proposição de metodologia para o design de embalagem orientada à sustentabilidade, Dissertação de Mestrado (Mestrado em Design), Universidade Federal do Rio Grande do Sul, Porto Alegre.

PMI. Um guia do conhecimento em gerenciamento de projetos (2017). Guia PMBOK® 6a. ed. - EUA: Project Management Institute.

Sastre, R.M. (2004), A embalagem como espaço alternativo de propaganda, Monografia de Graduação (Publicidade e Propaganda), Universidade do Vale do Rio dos Sinos, São Leopoldo.

Sastre, R.M. (2006), A importância da embalagem na formação do mercado de consumo brasileiro, Monografia de Pós-Graduação, PUC/RS, Porto Alegre.

Sastre, R.M. (2013), A inovação na embalagem, Monografia de MBA (MBA em Gestão Empresarial), IBGEN, Porto Alegre.

Sastre, R.M. (2014), Embalagem de consumo em papel cartão: Categorias para avaliação da inovação no Design e Produção de embalagens, Dissertação de Mestrado (Mestrado em Design), Centro Universitário Ritter dos Reis, Porto Alegre.

Sastre, R.M. (2015), “A gestão da produção gráfica centrada no design de embalagem”, Atitude, Vol. 6, pp. 149163 , Porto Alegre.

Sastre, R.M. (2016), "Análise semiótica comparativa no redesenho de embalagem do café Melitta", Espacios (Caracas), Vol. 37, p. 21, Venezuela.

Sastre, R.M. (2017), "Design de embalagem: os princípios de Redig na teoria da amplitude de Mestriner", Espacios (Caracas), Vol. 39, pp. 1-12, Venezuela.

Sastre, R.M., Paula, I.C. and Echeveste, M. (2018a), Design de embalagem: abordagens teóricas do Design sobre inovação, Blucher, São Paulo, pp. 289-30, ISSN 2318-6968, ISBN: cid201. https://doi.org/10.5151/cid2017-25

Sastre, R.M., Paula, I.C. and Echeveste, M. (2018b), "Proposition of guidelines for assessing innovation in the design and production of paperboard consumer packaging", International Design Conference, pp. 19571968. https://doi.org/10.21278/idc.2018.0292

Sastre, R.M. and Echeveste, M. (2019), "Development of Sustainable packages from industrial waste of the footwear sector", Leans Conference, Curitiba.

Sebrae Available at: http://www.sebrae.com.br/sites/PortalSebrae/ufs/sp/sebraeaz/pequenos-negocios-em-numer os, 12e8794363447510VgnVCM1000004c00210aRCRD (accessed 08.06.2019).

The Consumer Good Forum. Available at: https://www.theconsumergoodsforum.com/wp-content/uploads/2017/ 11/CGF-Global-Protocol-on-Packaging.pdf (accessed 05.11.2019).

World Packaging. Available at: https://www.worldpackaging.org (accessed 05.11.2019).

Zampori, L. (2013), "Design of a sustainable packaging in the food sector by applying LCA", Int J Life Cycle Assess. https://doi.org/10.1007/s11367-013-0618-9 